\title{
Studies on platelet 5-hydroxytryptamine in East Africans
}

\author{
BY M. A. CRAWFORD \\ Nuffield Institute of Comparative Medicine, The Zoological Society of London, \\ Regent's Park, London, NW I \\ AND I. L. HANSEN AND K. SOMERS \\ Departments of Medicine and Biochemistry, Makerere University College, \\ Kampala, Uganda
}

(Received I May 1969-Accepted 21 November 1969)

\begin{abstract}
I. A study was done on the platelet 5-hydroxytryptamine $(5 \mathrm{HT})$ from Africans in areas where endomyocardial fibrosis is common.

2. There were only small differences between the mean platelet or blood ${ }_{5} \mathrm{HT}$ in Europeans and plantain-eating Africans; the distribution of the results showed a wider scatter in the African community, including values outside the upper limits of normal but not within the range reported for carcinoid.

3. Patients in hospital had lower platelet ${ }_{5} \mathrm{HT}$ contents regardless of cardiac condition or disease than healthy Africans on similar diets, suggesting no specific abnormality related to platelet ${ }_{5} \mathrm{HT}$ levels and endomyocardial fibrosis.

4. A small number of radioactive studies suggested that only $\mathrm{I}-4 \%$ of oral $5 \mathrm{HT}$ may reach the platelets; a significant increase in platelet $5 \mathrm{HT}$ did occur after a plantain meal; the increase after a meal but not after oral ${ }_{5} \mathrm{HT}$ may be explained by release of endogenous ${ }_{5} \mathrm{HT}$ from the small intestine under the influence of the high bulk of the diet. Attention is drawn to the high incidence of adult intussusception and volvulus associated with such diets.
\end{abstract}

Cardiomyopathies are commonly encountered in the tropics but are rare in Europe. Of these, endomyocardial fibrosis (EMF) is of particular interest because in certain tropical communities it is a common cause of death from heart failure, whereas in other communities it is rarely seen. The geographical dependence of this disorder in Africa would seem consistent with foods rich in 5 -hydroxytryptamine $\left({ }_{5} \mathrm{HT}\right)$ and possibly with a dietary origin (Crawford, 1962, 1963; Foy \& Parratt, 1962). According to Shaper \& Coles (1965) the highest incidence of the disease is in the lower socioeconomic strata. From experience of an isolated instance in a European who had lived in Africa, Brockington, Olsen \& Goodwin ( 1967 ) claim that the disease cannot be caused by a genetic characteristic nor by dietary factors; they reviewed other cases, all of which had unusual backgrounds. No dietary histories were available and they reported on none of the dietary factors that might be relevant. Thomson (I96I) previously pointed out that a dietary aetiology could not be eliminated on such evidence. Shaper (1966) has discussed the postulate of a streptococcal reaction, analogous to rheumatic heart disease, but there is no convincing proof. van der Geld, Peetoom, Somers \& Kanyerezi ( 1966 ) have demonstrated heart auto-immune reactions from serological and immunological studies in endomyocardial fibrosis. Connor, Somers, Hutt, Manion \& D'Arbela (1967, I968) from detailed histopathology of endomyocardial fibrosis suggest the involvement of a vascular process in the myocardium.

In the carcinoid syndrome high blood $5 \mathrm{HT}$ levels have been thought to be 26

Nutr. 24, 2 
associated with fibrotic changes in the heart. Although the distribution of these changes within the heart is different from that in EMF, the fact that plantain is a rich source of ${ }_{5} \mathrm{HT}$ prompted us to study blood and platelet levels in Africans using plantain as a main staple.

\section{METHODS}

\section{Human subjects}

For platelet studies Africans were selected from three communities: (I) those known to use plantain as a main staple constituting at least $40 \%$ of the dietary bulk, i.e. Mengo, Bulemezi and Musaka (Dean \& Burgess, 1962; Bennett, Jelliffe, Jelliffe \& Moffat, I968; Uganda Atlas, I962). (2) non-plantain eaters (largely from West Nile and Kigezi) using sweet potato as a main staple; (3) a group from urban institutions where the diet is varied, with plantain, sweet potato, maize and cassava as main bulk foods.

Volunteers used for this study were all young adults ( $17-33$ years); the results reported here are for male subjects unless otherwise stated.

\section{Measurement of platelet 5 HT and plasma indoles}

Blood samples for determination of platelet $5 \mathrm{HT}$ in patients either with or without heart disease were obtained by venepuncture of an antecubital vein by means of disposable plastic syringes and wide-bore needles; ethylene diaminetetra-acetic acid $\left(\mathrm{I} \%\right.$ in $0.7 \% \mathrm{NaCl}$ ) was used as an anticoagulant and the samples were kept at $4^{\circ}$ until centrifugation, which was carried out as soon as possible after collection. Blood samples were taken between 08.30 and $\mathrm{I} .00 \mathrm{~h}$. The platelet fraction was separated in accordance with the method described by Hardisty \& Ingram (1965); the platelets were deep-frozen at $-15^{\circ}$ overnight and thawed on the following morning. $5^{\mathrm{HT}}$ was estimated either by the method of Udenfriend, Weissbach $\&$ Brodie (I958) or by direct fluorimetry; this was carried out after suspension in $2 \mathrm{ml} \mathrm{I} \mathrm{N}-\mathrm{HCl}$ and dialysis with $4 \mathrm{ml} \mathrm{O} \cdot \mathrm{I} \mathrm{N}-\mathrm{HCl}$ through Visking tubing at $4{ }^{\circ}$ for $18 \mathrm{~h}$. A portion $(2 \mathrm{ml})$ of the dialysate was treated with $0.6 \mathrm{ml}$ conc. $\mathrm{HCl}$ and the ${ }_{5} \mathrm{HT}$ measured in a Zeiss spectrofluorimeter. An excitation wavelength of $295 \mathrm{~nm}$ was used and the emission measured at $54^{\circ} \mathrm{nm}$. The platelet proteins were estimated by the method of Sutherland, Cori, Haynes \& Olsen (1949).

Platelet-free plasma obtained from the separation of the platelets was also dialised at $4^{\circ}$ and the equilibrium dialysate examined for 5-hydroxyindoles (mainly 5hydroxyindolylacetic acid, 5-HIAA) by direct fluorimetry and fluorimetry after extraction, as described by Udenfriend et al. (1958).

Radioactive measurements were made in a Packard Tricarb liquid scintillation counter with an internal radium standard. An attempt was made to study incorporation of orally administered $\left[{ }^{14} \mathrm{C}\right] 5 \mathrm{HT}$ into platelets. The test doses of $0 \cdot 1 \mu \mathrm{Ci}$ of ${ }^{14} \mathrm{C}$ labelled ${ }_{5} \mathrm{HT}$ were administered orally in water at $10.00 \mathrm{~h}$. Timed blood samples were taken at hourly intervals for $5 \mathrm{~h}$ and then at $8 \mathrm{~h}$; the ${ }_{5} \mathrm{HT}$ was isolated from the platelets chromatographically and counted, and the total amount incorporated was calculated by integrating the time curve. Urine was collected for $24 \mathrm{~h}$ and the 5 -HIAA and its conjugates were isolated chromatographically and counted. 


\section{Feeding experiments}

Feeding experiments were carried out with plantain, cooked in the traditional manner (matoke) by steaming the pulp sealed in leaves from the plant. Again blood samples were taken at timed intervals after the meal. The rat fundus method of Vane (1957) was used for confirmation of changes in $5 \mathrm{HT}$ measurements in feeding experiments with plantain (matoke) on eight African subjects who traditionally ate 'matoke'.

\section{RESULTS}

\section{Platelet ${ }_{5} H T$ in matoke eaters and Europeans}

For healthy subjects, not in hospital, there was a significant difference between the mean platelet $5 \mathrm{H}$ T of plantain-eating (matoke) African and that of non-plantain-eating Africans $(P<0.01)$. When compared with a European and Asian control group the African groups showed a much greater scatter (Fig. I) but there was no striking difference in the mean levels. Many of the observations fall outside the normal range (0.22-0.63 $\mu \mathrm{g} / \mathrm{mg}$ ) reported by Melmon \& Sjoerdsma (1963) for Americans and found by us for Europeans and Asians (Fig. I), but were not within the range expected for carcinoid.

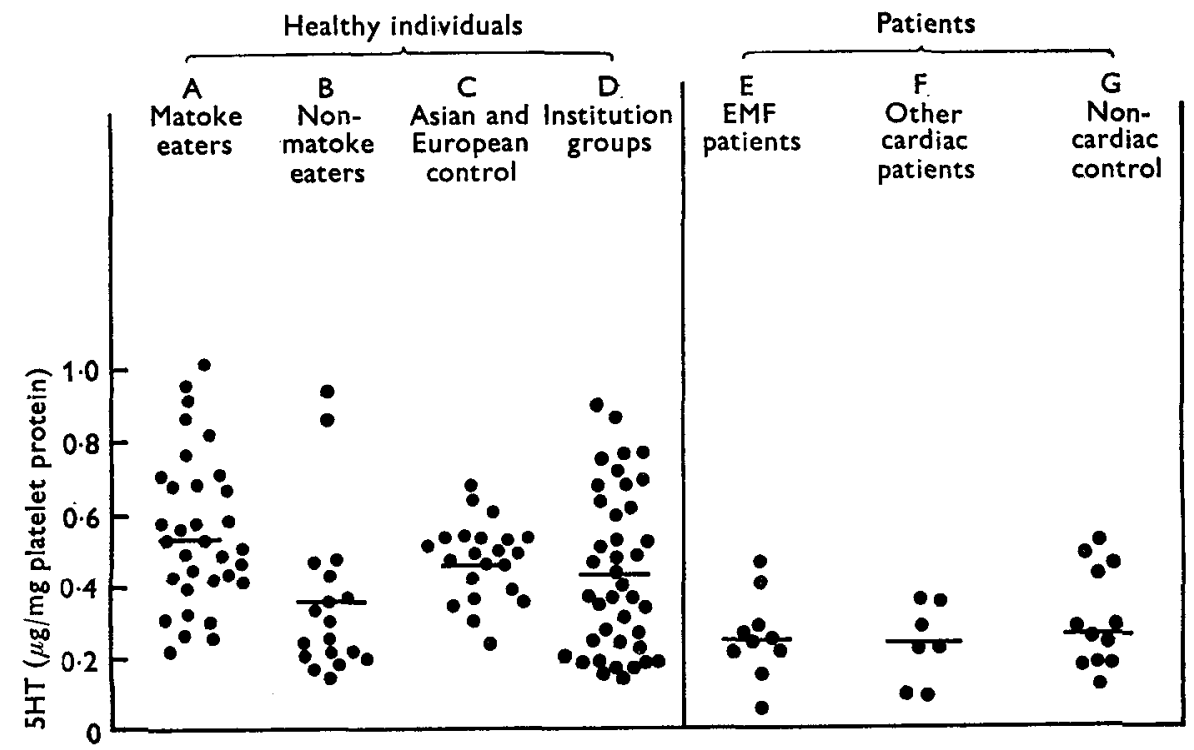

Fig. r. Scatter diagram of platelet 5 -hydroxytryptamine $\left({ }_{5} \mathrm{HT}\right)$ in Africans using matoke (plantain) as the main food, in different groups of Africans on a varied diet and in a group of Asian and European controls. ——, mean value; EMF, endomyocardial fibrosis.

Platelet levels in groups in hospital

All patients in hospital, from whatever cause, taking a standard hospital diet based on matoke, sweet potato, beans and maize, appeared to have lower levels of platelet ${ }_{5} \mathrm{HT}$ than the matoke-eating group not in hospital $(P<0.00 \mathrm{I}$; Fig. I). This hospital group should be considered as different from other groups reported here in so far as they were all at rest and would all have a lower dietary intake. 
Whole blood ${ }_{5} H T$ concentrations in matoke eaters and Europeans

The whole blood levels of $5 \mathrm{HT}$ in the plantain-eating African communities appeared to be significantly higher than in Europeans (0.01 $<P<0.05$ ) (Table I). In confirmation of the platelet studies the difference was small, but the scatter was wider in the African group.

Table I. Whole blood 5-hydroxytryptamine content $(\mu \mathrm{g} / \mathrm{ml})$ of Europeans and plantain-eating Africans

$\begin{array}{lcclc}\text { Subjects } & \text { No. } & \text { Mean } & \text { Range } & \text { SE } \\ \text { European } & 20 & 0.27 & 0.09-0.66 & 0.01 \\ \text { African } & 20 & 0.33 & 0.03-1 \cdot 7 & 0.04\end{array}$

Table 2. Platelet 5-hydroxytryptamine $\left({ }_{5} H T\right)$ and plasma 5 -hydroxyindoles $\left({ }_{5} \mathrm{OH}\right)$ in human subjects before and after an oral dose of $97 \mathrm{mg} 5 \mathrm{HT}$

\begin{tabular}{|c|c|c|c|c|c|c|}
\hline & \multicolumn{3}{|c|}{ Platelet ${ }_{5} \mathrm{H}^{\top} \mathrm{T}(\mu \mathrm{g} / \mathrm{mg}$ platelet protein) } & \multicolumn{3}{|c|}{ Plasma $5 \mathrm{OH}(\mu \mathrm{g} / \mathrm{ml}$ plasma $)$} \\
\hline & Before & $\begin{array}{c}\text { After } \\
2 \mathrm{~h}\end{array}$ & $\begin{array}{l}\text { After } \\
4-5 \mathrm{~h}\end{array}$ & Before & $\begin{array}{c}\text { After } \\
2 \mathrm{~h}\end{array}$ & $\begin{array}{l}\text { After } \\
4-5 h\end{array}$ \\
\hline \multicolumn{7}{|c|}{ EMF patients: } \\
\hline I & 0.21 & $0 \cdot 22$ & 0.21 & 0.08 & 0.28 & $0 \cdot 14$ \\
\hline 2 & 0.28 & 0.26 & 0.28 & 0.19 & 0.68 & 0.52 \\
\hline 3 & 0.26 & 0.29 & 0.26 & 0.09 & 0.33 & 0.32 \\
\hline 4 & 0.40 & 0.38 & 0.37 & 0.19 & $0 \cdot 37$ & 0.29 \\
\hline 5 & 0.23 & 0.22 & $0 \cdot 20$ & 0.15 & 0.32 & 0.26 \\
\hline 6 & 0.24 & 0.25 & 0.25 & 0.13 & 0.34 & 0.20 \\
\hline 7 & 0.46 & 0.43 & 0.47 & 0.19 & $0.3^{6}$ & 0.36 \\
\hline \multicolumn{7}{|c|}{ Other cardiac patients: } \\
\hline $\mathbf{I}$ & 0.21 & 0.23 & $0 \cdot 23$ & 0.10 & 0.28 & 0.27 \\
\hline 2 & 0.08 & 0.08 & 0.07 & 0.12 & 0.35 & 0.26 \\
\hline 3 & 0.08 & 0.08 & 0.09 & 0.23 & $0 \cdot 41$ & $0.4 \mathrm{I}$ \\
\hline 4 & 0.27 & 0.28 & 0.30 & 0.36 & 0.58 & 0.44 \\
\hline 5 & $0.2 \pi$ & 0.20 & $0 \cdot 28$ & 0.25 & 0.69 & $0.5 \mathrm{I}$ \\
\hline 6 & 0.35 & $0: 34$ & 0.30 & 0.24 & $0 \cdot 32$ & $0 \cdot 28$ \\
\hline \multicolumn{7}{|c|}{ Healthy Africans: } \\
\hline $\mathbf{I}$ & $0.9 \mathrm{I}$ & 0.88 & 0.85 & 0.10 & 0.26 & O.II \\
\hline 2 & 0.85 & 0.87 & 0.89 & 0.13 & 0.24 & 0.25 \\
\hline 3 & 0.16 & 0.14 & $0 \cdot 20$ & 0.31 & 0.44 & 0.22 \\
\hline 4 & 0.32 & 0.28 & $0 \cdot 30$ & 0.16 & 0.33 & 0.20 \\
\hline 5 & 0.28 & 0.26 & $0 \cdot 28$ & 0.17 & 0.33 & 0.19 \\
\hline 6 & 0.23 & 0.22 & 0.24 & 0.19 & 0.31 & 0.21 \\
\hline 7 & 0.60 & 0.63 & - & 0.08 & $0: 20$ & - \\
\hline \multicolumn{7}{|c|}{ Asian and European controls: } \\
\hline I & 0.48 & 0.50 & 0.45 & 0.08 & 0.27 & 0.27 \\
\hline 2 & 0.51 & 0.53 & 0.53 & $0 \cdot I I$ & 0.42 & 0.28 \\
\hline 3 & 0.49 & 0.52 & 0.53 & 0.17 & 0.34 & 0.15 \\
\hline 4 & 0.47 & 0.47 & 0.40 & 0.17 & 0.41 & 0.23 \\
\hline 5 & 0.30 & 0.32 & 0.29 & 0.15 & 0.37 & 0.18 \\
\hline 6 & 0.64 & 0.58 & 0.60 & 0.15 & 0.34 & 0.20 \\
\hline
\end{tabular}

\section{Feeding experiments}

The feeding experiments with ${ }_{5} \mathrm{HT}$ indicated that there was no significant increase in platelet ${ }_{5} \mathrm{HT}$ after an oral dose of $97 \mathrm{mg}{ }_{5} \mathrm{HT}$ (Table 2); there was, however, a significant increase in plasma 5 -hydroxyindoles. The $5 \mathrm{~h}$ blood sample showed that 
there was a difference in the patients with heart disease. In the majority of the healthy people the plasma 5 -hydroxyindole level had returned to normal after $5 \mathrm{~h}$; in the cardiac patients of either group levels remained elevated with a mean of $0.33 \mu \mathrm{g} / \mathrm{ml}$ as compared with a starting value of $0.18 \mu \mathrm{g} / \mathrm{ml}(P<0.00 \mathrm{I})$. In the healthy groups the means at this time differed from their starting values but with less significance $(0.025<P<0.05)$ (Table 2). Ojo \& Parratt (r966) comment that there was a delayed excretion of 5-HIAA in patients with endomyocardial fibrosis; our results suggest that this is common to all forms of cardiac failure examined (Table 2) and may be related to impairment of renal function.

Table 3. Platelet 5-hydroxytryptamine in eight Africans before and after a matoke meal

\begin{tabular}{|c|c|c|c|c|c|c|}
\hline & \multirow{2}{*}{\multicolumn{2}{|c|}{ Value }} & \multicolumn{4}{|c|}{$\%$ Difference compared with mean } \\
\hline & & & \multicolumn{2}{|c|}{$1 \cdot 5 \mathrm{~h}$} & \multicolumn{2}{|c|}{$3.5 \mathrm{~h}$} \\
\hline & Mean & SE & Mean & SE & Mean & SE \\
\hline${ }_{5} \mathrm{H}^{\prime} \mathrm{T}(\mu \mathrm{g} / \mathrm{mg}$ platelet protein) & $0.47(100 \%)$ & 0.10 & I 26 & $8 \cdot 9$ & 144 & 10.0 \\
\hline $\begin{array}{l}\text { Plasma 5-hydroxyindoles } \\
(\mu \mathrm{g} / \mathrm{ml})\end{array}$ & 0.093 & 0.01 & II 5 & $17 \cdot 5$ & 151 & $21 \cdot 6$ \\
\hline${ }_{5} \mathrm{HT}(\mu \mathrm{g} / \mathrm{g}$ plantain pulp $)$ & 68 & $6 \cdot 0$ & & & & \\
\hline
\end{tabular}

Table 4. Whole blood 5-hydroxytryptamine $\left({ }_{5} H T\right)(\mu g / m l)$, measured by rat fundus method, in healthy Africans before and after a matoke meal

$\begin{array}{cccc}\text { Subject } & \text { Before } & \begin{array}{l}\text { After } \\ \mathrm{I} .5 \mathrm{~h}\end{array} & \begin{array}{c}\text { After } \\ 3.5-4.5 \mathrm{~h}\end{array} \\ \mathbf{I} & 0.6 & 0.7 & 0.9 \\ 2 & 0.3 & 0.26 & 0.34 \\ 3 & 0.32 & 0.5 & 0.48 \\ 4 & 0.5 & 0.6 & \mathrm{I} \cdot 3 \\ 5 & 0.8 & 0.96 & \mathrm{I} \cdot 4 \\ 6 & 0.43 & 0.56 & \mathrm{I} \cdot 58 \\ 7 & 0.15 & 0.49 & 0.49 \\ 8 & 0.32 & 0.34 & 0.38\end{array}$

The wide scatter of the ${ }_{5} \mathrm{HT}$ levels, and in particular the high platelet levels associated with the healthy African communities, required explanation. Four preliminary attempts to establish the degree of radioactive incorporation into platelets from an oral dose of $0^{\circ} \mathrm{I} \mu \mathrm{Ci}{ }^{14} \mathrm{C}{ }_{5} \mathrm{HT}$ labelled in the methylene group showed that no more than $\mathrm{I}-4 \%$ of the administered dose reached the platelets; most of the activity was recovered as 5-HIAA (Table 5). On the other hand, a significant increase of platelet ${ }_{5} \mathrm{HT}$ (Table 3 ) and in whole blood ${ }_{5} \mathrm{HT}$ (Table 4 ) was noted after a simple plantain meal. Attempts to demonstrate monoamineoxidase inhibitors in cooked plantain have so far failed. Consequently, it seemed that orally administered ${ }_{5} \mathrm{HT}$ produced little change in the platelet content, whereas plantain (matoke) produced a detectable change.

In order to check that the fluorimetric method for ${ }_{5} \mathrm{HT}$ was measuring the active amine we repeated the feeding experiments and used the rat fundus technique for the 
assay of whole blood. The results (Table 4) appeared to confirm the fluorimetric analysis.

The oral administration of radioactive ${ }_{5} \mathrm{HT}$ demonstrated that only a small percentage of the activity would be detected in the isolated platelets $(\mathrm{I}-4 \%)$. Between 70 and $80 \%$ of the isotope was recovered as 5 -HIAA and its conjugates in urine over a $24 \mathrm{~h}$ period.

Table 5. Percentage recovery of ${ }^{14} \mathrm{C}$ in platelets and urine of Africans after oral administration of ${ }^{14} \mathrm{C}$-labelled 5 -hydroxytryptamine $\left({ }_{5} \mathrm{HT}\right)$

$\begin{array}{ccc} & \text { In platelets } & \\ (0-8 \mathrm{~h}) & \text { In urine (as } \\ (\text { as } 5 \mathrm{HT}) & 5 \text {-HIAA) } \\ 1 & 1 & 83 \\ 2 & 2 \cdot 3 & 74 \\ 3 & 1 \cdot 6 & 63 \\ 4 & 4 & 80\end{array}$

DISCUSSION

It seems that the process of endocardial fibrosis seen in carcinoid and attributed to ${ }_{5} \mathrm{HT}$ may not be a major factor in the aetiology of endomyocardial fibrosis. Such differences as were found between resting platelet or whole blood levels of ${ }_{5} \mathrm{HT}$ in the African plantain eaters do not fall within the levels experienced in carcinoid disease. Patients with endomyocardial fibrosis showed no difference in resting platelet $5 \mathrm{HT}$ when compared with other cardiac or non-cardiac hospital patients. Indeed, those that were examined in hospital had significantly lower platelet levels than normal subjects. People in this group would be both at rest and on a lower food intake. This fact tends to confirm the finding by Melmon \& Sjoerdsma (1963) and by us that a relationship exists between diet and platelet ${ }_{5} \mathrm{HT}$. This fact also indicates that there is no specific metabolic defect associated with the platelet ${ }_{5} \mathrm{HT}$ levels in endomyocardial fibrosis. As our understanding of the chronic disease process is still in its infancy, it would perhaps be inadvisable to exclude ${ }_{5} \mathrm{HT}$ as a contributory factor in view of the wide scatter of the normal African platelet and blood ${ }_{5} \mathrm{HT}$ levels, in some instances outside the normal range (Fig. I; Table $\mathrm{I}$ ); for example, platelets rich in ${ }_{5} \mathrm{HT}$ may release this vasoconstrictor more readily (Sjoerdsma, Weissbach, Terry \& Udenfriend, 1957; Melmon \& Sjoerdșma, 1963. The plasma 5-hydroxyindole (mainly 5-HIAA) levels will also increase in response to the intake of foodstuffs rich in ${ }_{5} \mathrm{HT}$ (Tables 2 and 3).

Our results with feeding experiments showed that orally administered ${ }_{5} \mathrm{HT}$ produced little change in platelet $5 \mathrm{HT}$ whilst an increase was detected after the plantain meal. An explanation for this anomaly could be found in two associated phenomena. In parts of Uganda the most common surgical emergencies are volvulus, double volvulus and adult intussusception. Both the findings of Burkitt, Nelson \& Williams (1963) and our own inquiries indicate a dividing line between communities in which these obstructive emergencies are common and rare. There has been some debate as 
to the reason for these obstructive disorders, but it has been shown in rats that highbulk diets do cause volvulus (Dowling, Ricken, Laws \& Booth, i967), and Burkitt et al. (1963) comment on the association of these disorders with high-bulk diets such as plantain and sweet potato.

The second relevant observation was the finding of a high excretion rate of indolylacrylylglycine and the free acid, a bacterial metabolite of tryptophan, in the urine of East Africans (Banwell \& Crawford, 1963; Crawford, 1964). The bacterial metabolites appear to be associated with high-bulk diets and to coincide with the geographic areas in Uganda in which intestinal obstruction is common (Crawford, I964; Crawford \& Hansen, unpublished observations). Surgeons working in areas of high incidence of obstructive disorders describe the high degree of small intestine motility seen on laparotomy which they do not observe when working in areas of low incidence. Consequently, there may be an association between obstructive disorders, increased small intestine motility and poor-quality diets of large bulk. The fact that the individuals with high platelet $5 \mathrm{HT}$ came from groups eating high-bulk diets suggests that these diets may stimulate the argentaffin cells of the small gut to release and synthesize ${ }_{5} \mathrm{HT}$, most of which would then be trapped by the platelets (Ghilinghelli \& Mira, 1960; Schmid \& Kunzlmeier, 1959; Bulbring \& Lin, 1958; Hendrix, Atkinson, Clifton \& Ingelfinger, 1957). Increased peristalsis has been shown in man to cause release of intestinal $5 \mathrm{HT}$ (Adams, I96I).

We do not yet know if a high-bulk diet rich in ${ }_{5} \mathrm{HT}$ produces more pronounced intestinal effects than one with a similar bulk but no ${ }_{5} \mathrm{HT}$. However, it is clear that the high bulk does produce a different rate of movement and a different gut structure. Evidence of an increased excretion of bacterial degradation products from amino acids is also seen in association with high-bulk, low-quality diets (Hansen \& Crawford, 1966). Whether these bacterial metabolites reflect a significant loss of amino acids is not yet known, but it is clear that a reduction in availability would be of importance to those who are exposed to low-protein diets.

This study was generously supported by grants nos. R 1568 and $R_{1780}$ of the Ministry of Overseas Development. We are also grateful to the British Empire Cancer Campaign, the East African Medical Research Council, Makerere University College Grants Committee and H. J. Heinz and Company for financial assistance.

We are grateful to the Uganda Game Department and members of the Medical Service who assisted in these inquiries.

We wish to thank Professor J. A. Locke for his advice on the rat fundus estimation of $5 \mathrm{HT}$ and Mrs S. M. Crawford who carried these out. Professor K. Somers is indebted to the British Heart Foundation for financial support.

\section{REFEREN CES}

Adams, B. G. (196r). Gut 2, 246.

Banwell, J. \& Crawford, M. A. (1963). Biochem. F. 89, 69 P.

Bennett, F., Jelliffe, D. B., Jelliffe, E. F. P. \& Moffat, M. (1968). E. Afr. med. F. 45, 229.

Brockington, I. F., Olsen, E. G. J. \& Goodwin, J. F. (I967). Lancet i, 583.

Bulbring, E. \& Lin, R. C. Y. (1958). F. Physiol., Lond. 140, 381 .

Burkitt, D. P., Nelson, C. L. \& Williams, E. H. (1963). E. Afr. med. F. 40, 1. 
Connor, D. H., Somers, K., Hutt, M. S. R., Manion, W. C. \& D'Arbela, P. G. (1967). Am. Heart F. 74,687 .

Connor, D. H., Somers, K., Hutt, M. S. R., Manion, W. C. \& D’Arbela, P. G. (1968). Am. Heart F. 75, 107.

Crawford, M. A. (1962). Lancet i, 352.

Crawford, M. A. (1963). Am. J. Med. 66, 273.

Crawford, M. A. (1964). E. Afr. med. F. 41, 228.

Dean, R. F. A. \& Burgess, H. J. L. (1962). E. Afr. med. $7.39,356$.

Dowling, R. H., Ricken, E. O., Laws, J. W. \& Booth, C. C. (1967). Clin. Sci. 32, I.

Foy, J. M. \& Parratt, J. R. (1962). Lancet i, 942.

Ghilinghelli, F. \& Mira, E. (1960). Rc. Ist. lomb. Sci. Cl. Sci. (B) 94, 3 I.

Hansen, I. L. \& Crawford, M. A. (1966). F. Chromat. 22, 330.

Hardisty, R. M. \& Ingram, G. I. C. (1965). In Bleeding Disorders, p. 225. London: Blackwell.

Hendrix, T. R., Atkinson, M., Clifton, J. A. \& Ingelfinger, F. J. (1957). Am. F. Med. $23,886$.

Melmon, K. \& Sjoerdsma, A. (1963). Lancet ii, 316.

Ojo, G. O. \& Parratt, J. R. (I966). Lancet i, 854 .

Schmid, E. \& Kunzlmeier, H. (1959). Gastroenterologia 9r, 248.

Shaper, A. G. (I966). Lancet i, 639.

Shaper, A. G. \& Coles, R. M. (1965). Br. Heart 7. 27, I 2 I.

Sjoerdsma, A., Weissbach, H., Terry, L. L. \& Udenfriend, S. (1957). Am. F. Med. 23, 5.

Sutherland, E. W. Cori, C. F., Haynes, R. \& Olsen, N. S. (1949). F. biol. Chem. 180, 825.

Thomson, J. G. (1961). In Recent Advances in Human Nutrition Ch. 3o. Boston: Little, Brown and Company.

Udenfriend, S., Weissbach, H. \& Brodie, B. B. (1958). Meth. biochem. Analysis 6, 95.

Uganda Atlas (1962). Lands and Surveys Department, Uganda Government.

van der Geld, H., Peetoom, F., Somers, K. \& Kanyerezi, B. R. (1 g66). Lancet ii, Izro.

Vane, J. R. (1957). Br. F. Pharmac. Chemother. 12, 344. 